\title{
The Current Situation of Primary School Teacher's Evaluation in China-Take the Several Schools in Nantong City as Example
}

\author{
Zhiquan Zhang', ${ }^{1}$ Jieyin $^{2}$, Chenyun $\mathrm{CAI}^{3}$ \\ Educational Science Faculty of Nantong University \\ JiangSu province China 226019 \\ ${ }^{1}$ zzhq110@sina.com
}

\begin{abstract}
Education is a social activity in cultivating talent, the quality of talent education is decided not only affected by education aim, but also affected the way of cultivating and evaluating talent. As the direct executor, teacher's quality and ability affect the quality of talent. In order to ensure teacher's quality, we need to build a system of teacher's evaluation on basis of the investigation of the evaluation on teacher in many primary schools in China. So in this article, we carry on a investigation about how school evaluate teacher, how teacher evaluate themselves, how teacher evaluate student and how student evaluate teacher. Then according to the result of the investigation. Some suggestions were given on how to improve the evaluation about teacher in school.
\end{abstract}

Keyword: Teacher's evaluation; Student's quality; Teacher and student's concord development; Student's incremental evaluation.

Evaluation has important function on people's development. If we evaluate one student who is not good at studying as diligent but not clever, he will lose his confidence, but if we evaluate him as clever but not diligent, that will make him be more diligent. Also, in like manner, If we evaluate a teacher who can develop more talents of the student's as good teacher. Teacher will try their best to develop student's more talents. While if we evaluate a teacher who can make student get high score as good teacher ,teacher will take every way to make student know how to get high score in every tests and will not pay attention to student's development on other aspect. So evaluation has the function of leading, monitoring and inspiring teacher's and student's development. So making a research and investigation about the evaluation on teacher is a great importance to the improving of education quality.

\section{INTRODUCTION}

Table1.1. Information of teacher

\begin{tabular}{|c|c|c|c|c|c|c|c|c|}
\hline \multirow{2}{*}{$\begin{array}{c}\text { sample } \\
\text { Characteristic }\end{array}$} & \multicolumn{4}{|c|}{ School } & \multicolumn{4}{|c|}{ Sex } \\
\hline & $\begin{array}{l}\text { Eight one } \\
\text { primary } \\
\text { school }\end{array}$ & \multicolumn{2}{|c|}{$\begin{array}{l}\text { Lu Hongzha } \\
\text { primary school }\end{array}$} & $\begin{array}{c}\text { Development Zone } \\
\text { Experimental } \\
\text { Primary School }\end{array}$ & \multicolumn{2}{|c|}{ male } & \multicolumn{2}{|c|}{ female } \\
\hline $\begin{array}{l}\text { Sample } \\
\text { number }\end{array}$ & 38 & \multicolumn{2}{|c|}{30} & 74 & \multicolumn{2}{|l|}{34} & \multicolumn{2}{|c|}{108} \\
\hline percent $(\%)$ & 26.8 & \multicolumn{2}{|c|}{21.1} & 52.1 & 23.9 & & \multicolumn{2}{|c|}{76.1} \\
\hline \multirow{2}{*}{$\begin{array}{c}\text { sample } \\
\text { Characteristic }\end{array}$} & \multicolumn{4}{|c|}{ Age } & \multicolumn{4}{|c|}{ Teaching time } \\
\hline & $<30$ & $30-40$ & $41-50$ & $>50$ & $<3$ & $3-8$ & $9-15$ & $>15$ \\
\hline $\begin{array}{l}\text { Sample } \\
\text { number }\end{array}$ & 34 & 82 & 18 & 8 & 22 & 22 & 46 & 52 \\
\hline percent $(\%)$ & 23.9 & 57.7 & 12.7 & 5.6 & 15.5 & 15.5 & 32.4 & 36.6 \\
\hline \multirow{2}{*}{$\begin{array}{c}\text { sample } \\
\text { Characteristic }\end{array}$} & \multicolumn{4}{|c|}{ Educational record } & \multicolumn{4}{|c|}{ professional title } \\
\hline & specialty & junior & bachelor & master & $\begin{array}{c}\text { The } \\
\text { primary }\end{array}$ & $\begin{array}{c}\text { Primary } \\
\text { level }\end{array}$ & $\begin{array}{c}\text { Level } \\
2\end{array}$ & $\begin{array}{l}\text { Senior } \\
\text { level }\end{array}$ \\
\hline $\begin{array}{l}\text { Sample } \\
\text { number }\end{array}$ & 2 & 22 & 114 & 4 & 72 & 40 & 26 & 4 \\
\hline percent $(\%)$ & 1.4 & 15.5 & 80.3 & 2.8 & 50.7 & 28.2 & 18.3 & 2.8 \\
\hline
\end{tabular}




\section{Zhiquan Zhang et al.}

Teacher evaluation has been the focus of educators' attention in recent years, while primary school teacher's evaluation becomes the priority. Nantong is one of renowned cities for education. It has been a leader in the field of basic education in Jiangsu. It has large number of teachers with high quality especially in basic education. However, there has been no systematic study on teachers' evaluation of the status in primary schools in Nantong area. Therefore, no one can provide reasonable solutions to problems which have been existed in teacher evaluation. In order to change this situation, in this article, we analyze on the current situation of teacher evaluation from the three dimensions of school, teachers and students. In order to understand the status of primary school teachers' evaluation in Nantong, we select 373 students and 142 teachers in three schools. The exact number is list 1-1 and $1-2$.

Table1.2. information of primary school student

\begin{tabular}{|c|c|c|c|c|c|c|c|c|}
\hline \multirow{2}{*}{$\begin{array}{c}\text { Sample } \\
\text { characteristics }\end{array}$} & \multicolumn{3}{|c|}{ School } & \multicolumn{2}{|c|}{ Sex } & \multicolumn{3}{c|}{ Grade } \\
\cline { 2 - 9 } & $\begin{array}{c}\text { Eight one } \\
\text { primary } \\
\text { school }\end{array}$ & $\begin{array}{c}\text { Lu Hongzha } \\
\text { primary } \\
\text { school }\end{array}$ & $\begin{array}{c}\text { Development Zone } \\
\text { Experimental } \\
\text { Primary School }\end{array}$ & male & female & 3 & 4 & 5 \\
\hline Sample number & 135 & 80 & 158 & 202 & 171 & 80 & 95 & 198 \\
\hline percent (\%) & 36.2 & 21.4 & 42.4 & 54.2 & 45.8 & 21.4 & 25.5 & 53.1 \\
\hline
\end{tabular}

\subsection{Measure}

\subsubsection{School Level}

This study conducted interviews with five primary school principals in Nantong city. Among them, two principals were male and three principals were female. One principal's qualification is college, four principals are undergraduate. Five principals are the title of senior primary school teachers, and their teaching experience are more than 15 years.

\subsubsection{Teacher Level}

The object of this study is primary school teacher in Nantong city, Taking into account the different levels of school teacher evaluation will be different, Therefore, three different types of schools were selected, they are eight one primary school (urban and rural primary school), Lu Hongzha primary school (rural primary school), Development Zone Experimental Primary School (urban primary school). Teacher evaluation questionnaire design a total of 18 questions from the three dimensions of teachers' view on the school's evaluation, on students and teachers' self evaluation, including singlechoice questions, multiple-choice questions and one open question.

\subsubsection{Student Level}

This study respectively selects a class from third, fourth, fifth grade of Eight One, Lu HongZha, The Development Zone Experimental Primary School. Student evaluation questionnaire was designed with 20 questions from two dimensions: self evaluation and evaluation of teachers, including the single, multiple-choice and open-ended questions.

\subsection{Method}

Use Spss20.0 software to analyze the data.

\section{RESEARCH OUTCOME}

\subsection{Evaluation on Teachers from Schools}

\subsubsection{The Situation of Evaluation on Teacher from School}

'Does your school have a systemically evaluation on teachers?'On this issue, the five principals interviewed described the status of their school.

"Our school has a relatively complete system of teacher evaluation, mainly has been implemented in < performance evaluation and implementation plan >, specifically manifested in the following aspects: 1. Ethics; 2. Safety management; 3. Attendance; 4. Workload; 5. The teaching quality; 6. Teaching and research achievements; 7. Teacher professional development; 8. Excellent talent evaluation; 9. Good team; 10. Special contribution allowance; 11. Lifelong Teaching Award." 
"The system of the evaluation of teachers in our school, specific performance in: ethics, education and teaching ability, dedication and work performance"

- Interview records of principal Zhu

"Our school has a system of teacher evaluation system. The specific performance in the identification of outstanding teachers, the public opinion of the teacher group and the way of performance"

- Interview records of principal Cai

"Our school has a system of teacher evaluation. Specific performance in professional ethics, the work of a teacher in charge of a class, teaching attitude seriously, the workload of security duty, the activities of the organization, teaching and research achievements, individual and team collaboration."

- Interview records of principal Luo

"Our school has teacher evaluation system. Specific performance in: 1. Professional ethics: dedication, law-abiding, teacher; 2. Knowledge: Master teaches discipline knowledge, combined with teaching practice; 3 . Teaching ability: well-organized teaching, excellent management capabilities. Cultural literacy: lifelong learning, knowledge and extensive influence on students; 5 . In the ability of working: has the team spirit and good coordination of all aspects of the relationship."

- Interview records of principal Wang

Throughout the interview to principals, all schools have a teacher evaluation program of their own, although there are differences in details, but mainly focus on Teachers' morality, professional ability, work performance, achievements in scientific research and the quality of personal ability aspects.

\subsubsection{The significance of school teacher evaluation}

All the principals have talked about the most direct and close relationship between teacher evaluation and teacher development, and it also affects the sustainable and healthy development of the whole school. Among them, Zhu and Luo also mentioned that teacher evaluation not only has a direct impact on teachers, but also affects the development of students.

"Teacher evaluation is the starting point of the school management; is the goal and direction of teacher education and teaching; but also enhance the grade of school culture, social image."

_- Interview records of principal Zhang

"Teacher evaluation can promote the overall optimization of the teacher's own quality and the overall optimization of the teacher's function, forging an excellent teacher team, and also affect the development of the school"

- Interview records of principal Zhu

"Teacher evaluation has a positive impact on the healthy development of students' physical and mental health. It plays a positive role in promoting the sustainable development of teachers, and has a far-reaching impact on the sustainable development of the school."

- Interview records of principal Cai

"Teacher evaluation can help teachers to find a sense of identity, to promote the professional development of all teachers, and promote the development of the school."

Interview records of principal Luo

"Teacher evaluation affects a school teacher quality, school spirit and style; determines the process and the height of the development of teachers; decided to cultivate what kind of people and in which way to develop a person."

\subsubsection{Attitudes towards Teachers' Self Assessment}

-Interview records of principal Wang

All the principals have talked about the most direct and close relationship between teacher evaluation and teacher development, and it also affects the sustainable and healthy development of the whole school. Among them, Zhu and Luo, the principals also mentioned that teacher evaluation not only has a direct impact on teachers, but also affects the development of students. 


\subsubsection{Views on the Influence of Teachers' Self Evaluation on Students}

Although all principals have different views, but they all show a meaning, that is, teachers' self evaluation will has a great influence on Teachers' evaluation to students and the development of the students. And in the interview process, the author from the look on the faces of the principals, attitude feel their attention to this problem.

"Teacher" s self - assessment will fundamentally change his personal education teaching concept, improve his daily teaching behavior, thus more objective and scientific evaluation of students, promote students to better, more comprehensive development "

- Interview records of principal Zhang

"Teachers' self evaluation and teacher evaluation on student development was positively correlated. Teachers self-evaluation is closely related to scientific view of education, students view, and it has a long-term impact on the healthy growth of students body and mind."

_- Interview records of principal Zhu

"Teachers' self evaluation will play a direct role of teachers on students' evaluation and development of the students. Because education work is the spirit and soul of the cultivation, teachers' psychological health, spiritual realm will directly reflected in education."

- Interview records of principal Cai

"Teacher" s self - Assessment determines the direction of the development of students. In other words, if the content of self - Evaluation of teachers, the concept cannot stand in a higher field of vision, the training of students can only be mediocre"

- Interview records of principal Luo

"Teachers who can correctly evaluate themselves will guide students to self evaluation, and have a positive impact on the development of students"

_- Interview records of principal Wang

\subsection{Teachers' Evaluation of Themselves}

\subsubsection{The Importance of Teachers' Self Evaluation}

Table2-1. The importance of teacher self evaluation $(N=142)$

\begin{tabular}{|c|c|c|c|c|c|c|}
\hline & \multicolumn{4}{|c|}{ Which do you think is the importance of teachers' self evaluation? } \\
\hline & & & \multirow[t]{2}{*}{\begin{tabular}{|c|} 
To guide \\
teachers to feel \\
and to seek their \\
own progress in \\
all aspects \\
28 \\
\end{tabular}} & \multirow[t]{2}{*}{$\begin{array}{c}\text { Respect } \\
\text { and trust } \\
\text { of } \\
\text { Teachers } \\
16\end{array}$} & \multirow[t]{2}{*}{\begin{tabular}{|c|} 
Reduce the pressure from \\
the external evaluation of \\
teachers, enhance the \\
independent consciousness \\
of teachers' development \\
16
\end{tabular}} & \multirow[t]{2}{*}{\begin{tabular}{|c} 
Meaning is not \\
very big, the \\
teacher seldom \\
can evaluate \\
oneself
\end{tabular}} \\
\hline \multirow[t]{6}{*}{ school } & \multirow{2}{*}{$\begin{array}{c}\text { Eight one } \\
\text { primary school }\end{array}$} & count & & & & \\
\hline & & $\%$ in school & $73.7 \%$ & $42.1 \%$ & $42.1 \%$ & $5.3 \%$ \\
\hline & \multirow{2}{*}{$\begin{array}{c}\text { Lu Hongzha } \\
\text { primary school }\end{array}$} & count & 26 & 18 & 10 & 2 \\
\hline & & $\%$ in school & $86.7 \%$ & $60.0 \%$ & $33.3 \%$ & $6.7 \%$ \\
\hline & \multirow{2}{*}{$\begin{array}{c}\text { Development } \\
\text { Zone } \\
\text { Experimental } \\
\text { Primary School }\end{array}$} & count & 50 & 40 & 28 & 4 \\
\hline & & $\%$ in school & $67.6 \%$ & $54.1 \%$ & $37.8 \%$ & $5.4 \%$ \\
\hline \multirow{2}{*}{\multicolumn{2}{|c|}{ total }} & count & 104 & 74 & 54 & 8 \\
\hline & & $\%$ of total & $73.2 \%$ & $52.1 \%$ & $38.0 \%$ & $5.6 \%$ \\
\hline
\end{tabular}

As shown in table 2-1, a total of 142 people, per teacher can choose two options. The total number of selections of the less than or equal to 284 ( $2 \times 142)$. As shown in table 2-2, the number of valid cases is 240.Thereforethe statistic is valid. According to the table 2-2,the variable of school has no significant result on teachers' awareness of the importance of self evaluation(with a probability of more than 0.05). 
The Current Situation of Primary School Teacher's Evaluation in China-Take the Several Schools in Nantong City as Example

Table2-2. Chi-Square Tests

\begin{tabular}{|c|c|c|c|c|c|c|c|c|c|}
\hline & \multirow[t]{3}{*}{ Value } & \multirow[t]{3}{*}{ df } & \multirow{3}{*}{$\begin{array}{c}\text { Asymp. Sig. } \\
\text { (2-sided) }\end{array}$} & \multicolumn{3}{|c|}{ Monte Carlo Sig. (2-sided) } & \multicolumn{3}{|c|}{ Monte Carlo Sig. (1-sided) } \\
\hline & & & & \multirow[t]{2}{*}{ Sig. } & \multicolumn{2}{|c|}{$\begin{array}{l}\text { 95\% Confidence } \\
\text { Interval }\end{array}$} & \multirow[t]{2}{*}{ Sig. } & \multicolumn{2}{|c|}{$\begin{array}{l}\text { 95\% Confidence } \\
\text { Interval }\end{array}$} \\
\hline & & & & & $\begin{array}{l}\text { Lower } \\
\text { Bound }\end{array}$ & $\begin{array}{l}\text { Upper } \\
\text { Bound }\end{array}$ & & $\begin{array}{l}\text { Lower } \\
\text { Bound }\end{array}$ & $\begin{array}{l}\text { Upper } \\
\text { Bound }\end{array}$ \\
\hline $\begin{array}{c}\text { Pearson Chi- } \\
\text { Square }\end{array}$ & $1.879^{\mathrm{a}}$ & 6 & .930 & $.936^{\mathrm{b}}$ & .932 & .941 & & & \\
\hline Likelihood Ratio & 1.932 & 6 & .926 & $.935^{\mathrm{b}}$ & .930 & .940 & & & \\
\hline $\begin{array}{c}\text { Fisher's Exact } \\
\text { Test }\end{array}$ & 2.103 & & & $.922^{b}$ & .917 & .927 & & & \\
\hline $\begin{array}{l}\text { Linear-by- } \\
\text { Linear } \\
\text { Association }\end{array}$ & $.048^{\mathrm{c}}$ & 1 & .827 & $.860^{\mathrm{b}}$ & .853 & .867 & $.442^{b}$ & .432 & .452 \\
\hline $\begin{array}{c}\mathrm{N} \text { of Valid } \\
\text { Cases }\end{array}$ & 240 & & & & & & & & \\
\hline \multicolumn{10}{|c|}{ a. 3 cells $(25.0 \%)$ have expected count less than 5 . The minimum expected count is 1.87 . } \\
\hline \multicolumn{10}{|c|}{ b. Based on 10000 sampled tables with starting seed 2110151063.} \\
\hline \multicolumn{10}{|c|}{ c. The standardized statistic is .218 . } \\
\hline
\end{tabular}

This shows that the vast majority of teachers are aware of the importance of teacher self-evaluation and identify the teacher self-evaluation. And most of the teachers awake to that self-evaluation has extremely important significance on enhancing self-awareness and trust respect for teachers. However, few teachers are not aware of the importance of self assessment.

\subsubsection{The Purpose of Teacher Self Evaluation}

Table2-3. The purpose of teacher self evaluation $(N=142)$

\begin{tabular}{|c|c|c|c|c|c|c|}
\hline & \multicolumn{4}{|c|}{ What do you think is the purpose of teacher self evaluation? } \\
\hline & & & $\begin{array}{l}\text { To cope with the } \\
\text { assessment of } \\
\text { the school }\end{array}$ & $\begin{array}{l}\text { discover the } \\
\text { Problems in the } \\
\text { teaching } \\
\text { Independently }\end{array}$ & $\begin{array}{c}\text { Promote their } \\
\text { professional } \\
\text { development }\end{array}$ & $\begin{array}{c}\text { promote } \\
\text { students to } \\
\text { develop better }\end{array}$ \\
\hline \multirow[t]{6}{*}{ school } & \multirow{2}{*}{$\begin{array}{c}\text { Eight one primary } \\
\text { school }\end{array}$} & count & 6 & 22 & 26 & 4 \\
\hline & & $\begin{array}{c}\% \text { in } \\
\text { school }\end{array}$ & $15.8 \%$ & $57.9 \%$ & $68.4 \%$ & $10.5 \%$ \\
\hline & \multirow{2}{*}{$\begin{array}{l}\text { Lu Hongzha } \\
\text { primary school }\end{array}$} & count & 0 & 22 & 20 & 12 \\
\hline & & $\begin{array}{c}\% \text { in } \\
\text { school }\end{array}$ & $0.0 \%$ & $73.3 \%$ & $66.7 \%$ & $40.0 \%$ \\
\hline & \multirow{2}{*}{$\begin{array}{c}\text { Development Zone } \\
\text { Experimental } \\
\text { Primary School }\end{array}$} & count & 6 & 60 & 52 & 16 \\
\hline & & $\begin{array}{c}\% \text { in } \\
\text { school }\end{array}$ & $8.1 \%$ & $81.1 \%$ & $70.3 \%$ & $21.6 \%$ \\
\hline \multirow{2}{*}{\multicolumn{2}{|c|}{ total }} & count & 12 & 104 & 98 & 32 \\
\hline & & $\%$ of total & $8.5 \%$ & $73.2 \%$ & $69.0 \%$ & $22.5 \%$ \\
\hline
\end{tabular}

Table2-4. Chi-Square Tests

\begin{tabular}{|c|c|c|c|c|c|c|c|c|c|}
\hline & \multirow[t]{3}{*}{ Value } & \multirow[t]{3}{*}{$\mathrm{df}$} & \multirow{3}{*}{$\begin{array}{l}\text { Asymp. Sig. } \\
\text { (2-sided) }\end{array}$} & \multicolumn{3}{|c|}{ Monte Carlo Sig. (2-sided) } & \multicolumn{3}{|c|}{ Monte Carlo Sig. (1-sided) } \\
\hline & & & & \multirow[t]{2}{*}{ Sig. } & \multicolumn{2}{|c|}{$\begin{array}{l}95 \% \text { Confidence } \\
\text { Interval }\end{array}$} & \multirow[t]{2}{*}{ Sig. } & \multicolumn{2}{|c|}{$\begin{array}{l}95 \% \text { Confidence } \\
\text { Interval }\end{array}$} \\
\hline & & & & & $\begin{array}{l}\text { Lower } \\
\text { Bound }\end{array}$ & $\begin{array}{l}\text { Upper } \\
\text { Bound }\end{array}$ & & $\begin{array}{l}\text { Lower } \\
\text { Bound }\end{array}$ & $\begin{array}{l}\text { Upper } \\
\text { Bound }\end{array}$ \\
\hline Pearson Chi-Square & $12.531^{\mathrm{a}}$ & 6 & .051 & $.049^{\mathrm{b}}$ & .045 & .053 & & & \\
\hline Likelihood Ratio & 14.015 & 6 & .029 & $.038^{\mathrm{b}}$ & .034 & .041 & & & \\
\hline Fisher's Exact Test & 11.749 & & & $.058^{\mathrm{b}}$ & .054 & .063 & & & \\
\hline $\begin{array}{l}\text { Linear-by-Linear } \\
\text { Association }\end{array}$ & $.133^{\mathrm{c}}$ & 1 & .716 & $.732^{\mathrm{b}}$ & .723 & .741 & $.384^{\mathrm{b}}$ & .374 & .394 \\
\hline $\mathrm{N}$ of Valid Cases & 246 & & & & & & & & \\
\hline \multicolumn{10}{|c|}{ a. 2 cells $(16.7 \%)$ have expected count less than 5 . The minimum expected count is 2.63 . } \\
\hline \multicolumn{10}{|c|}{ b. Based on 10000 sampled tables with starting seed 605580418 . } \\
\hline \multicolumn{10}{|c|}{ c. The standardized statistic is .364 . } \\
\hline
\end{tabular}




\section{Zhiquan Zhang et al.}

As shown in Table 2-3, a total of 142 people, per teacher can choose two options. The total number of selections is less than or equal to 284 ( $2 \times 142)$; As shown in table 2-4, the number of valid cases is 246.Thereforethe statistic is valid. According to the table 2-4, the variable of school has no significant result on teachers' awareness of the purpose of self evaluation (with a probability of more than 0.05).

From the results of the survey, teachers think the main purpose of teacher self-evaluation is to find problems of teaching and improve the quality of teaching. As the purpose of the assessment of development, the majority of teachers has also paid enough attention to promote their own professional development, which is the new curriculum reform of teachers' self rating proposed new requirements. It is worth mentioning that the attitude of teachers on teachers' self evaluation can promote students to develop better in different schools exists difference.

\subsubsection{Methods of Teacher Self Evaluation}

Table2-5. Methods of teacher self evaluation

\begin{tabular}{|c|c|c|c|c|c|c|}
\hline & \multicolumn{4}{|c|}{$\begin{array}{l}\text { Which the following methods would you like to make a self - } \\
\text { evaluation? }\end{array}$} \\
\hline & & & $\begin{array}{c}\text { Reflexive } \\
\text { method }\end{array}$ & $\begin{array}{c}\text { Value added } \\
\text { evaluation method }\end{array}$ & $\begin{array}{c}\text { Comparative } \\
\text { method }\end{array}$ & $\begin{array}{l}\text { Self archiving } \\
\text { method }\end{array}$ \\
\hline \multirow[t]{6}{*}{ school } & \multirow{2}{*}{$\begin{array}{l}\text { Eight one primary } \\
\text { school }\end{array}$} & count & 28 & 36 & 18 & 8 \\
\hline & & $\%$ in school & $73.7 \%$ & $94.7 \%$ & $47.4 \%$ & $21.1 \%$ \\
\hline & \multirow{2}{*}{$\begin{array}{l}\text { Lu Hongzha primary } \\
\text { school }\end{array}$} & count & 22 & 24 & 6 & 6 \\
\hline & & $\%$ in school & $73.3 \%$ & $80.0 \%$ & $20.0 \%$ & $20.0 \%$ \\
\hline & \multirow{2}{*}{$\begin{array}{c}\text { Development Zone } \\
\text { Experimental Primary } \\
\text { School }\end{array}$} & count & 52 & 46 & 30 & 26 \\
\hline & & $\%$ in school & $72.2 \%$ & $63.9 \%$ & $41.7 \%$ & $36.1 \%$ \\
\hline \multirow{2}{*}{\multicolumn{2}{|c|}{ total }} & count & 102 & 106 & 54 & 40 \\
\hline & & $\%$ of total & $72.9 \%$ & $75.7 \%$ & $38.6 \%$ & $28.6 \%$ \\
\hline
\end{tabular}

Table2-6. Chi-Square Tests

\begin{tabular}{|c|c|c|c|c|c|c|c|c|c|}
\hline \multicolumn{10}{|c|}{ Table 2-6Chi-Square Tests } \\
\hline & \multirow[t]{3}{*}{ Value } & \multirow[t]{3}{*}{ df } & \multirow{3}{*}{$\begin{array}{l}\text { Asymp. Sig. } \\
\text { (2-sided) }\end{array}$} & \multicolumn{3}{|c|}{ Monte Carlo Sig. (2-sided) } & \multicolumn{3}{|c|}{ Monte Carlo Sig. (1-sided) } \\
\hline & & & & \multirow[t]{2}{*}{ Sig. } & \multicolumn{2}{|c|}{$95 \%$ Confidence Interval } & \multirow[t]{2}{*}{ Sig. } & \multicolumn{2}{|c|}{$95 \%$ Confidence Interval } \\
\hline & & & & & $\begin{array}{l}\text { Lower } \\
\text { Bound }\end{array}$ & $\begin{array}{l}\text { Upper } \\
\text { Bound }\end{array}$ & & $\begin{array}{l}\text { Lower } \\
\text { Bound }\end{array}$ & $\begin{array}{l}\text { Upper } \\
\text { Bound }\end{array}$ \\
\hline Pearson Chi-Square & $8.438^{\mathrm{a}}$ & 6 & .208 & $.208^{\mathrm{b}}$ & .200 & .216 & & & \\
\hline Likelihood Ratio & 8.828 & 6 & .183 & $.192^{\mathrm{b}}$ & .184 & .200 & & & \\
\hline Fisher's Exact Test & 8.357 & & & $.210^{\mathrm{b}}$ & .202 & .218 & & & \\
\hline $\begin{array}{c}\text { Linear-by-Linear } \\
\text { Association }\end{array}$ & $1.239^{c}$ & 1 & .266 & $.274^{\mathrm{b}}$ & .265 & .283 & $.138^{\mathrm{b}}$ & .131 & .145 \\
\hline $\mathrm{N}$ of Valid Cases & 302 & & & & & & & & \\
\hline \multicolumn{10}{|c|}{ a. 0 cells $(0.0 \%)$ have expected count less than 5 . The minimum expected count is 7.68 . } \\
\hline J & ed & & h starting & ed 20 & 5597102. & & & & \\
\hline
\end{tabular}

As shown in table 2-5, a total of 142 people, per teacher can choose three options. The total number of selections is less than or equal to 426 ( $3 \times 142$ ); As shown in table 2-6, the number of valid cases is 302. Therefore the statistic is valid. According to the table 2-6, the variable of school has no significant result on teachers' choice of the method of self evaluation (with a probability of more than $0.05)$.

Teachers' favorite methods of self evaluation are reflexive method and Value added evaluation method. Comparative method is an important channel for teachers to obtain self perception and evaluation. Teachers can find their own shortcomings and make up the defects quickly by making comparison with colleagues. Few teachers make a self evaluation through the self archiving method. This may be due to the heavy pedagogical tasks. Teachers should spend additional time on preparing for tomorrow's teaching after they get off work in China, so that they have no extra time time to archive their own career situation. 
The Current Situation of Primary School Teacher's Evaluation in China-Take the Several Schools in Nantong City as Example

\subsubsection{Content of Teachers' Self-Assessment}

Table2-7. Content of teachers' self-assessment

\begin{tabular}{|c|c|c|c|c|c|c|}
\hline & \multicolumn{4}{|c|}{$\begin{array}{l}\text { Which aspects should be included in the content of teachers' self } \\
\text { evaluation? }\end{array}$} \\
\hline & & & $\begin{array}{l}\text { Educational } \\
\text { ideals and } \\
\text { beliefs }\end{array}$ & $\begin{array}{c}\text { Knowledge, } \\
\text { ability and } \\
\text { morality }\end{array}$ & $\begin{array}{l}\text { emotion and } \\
\text { attitude to teaching } \\
\text { and students' }\end{array}$ & $\begin{array}{l}\text { Teaching } \\
\text { result }\end{array}$ \\
\hline \multirow[t]{6}{*}{ school } & \multirow{2}{*}{$\begin{array}{l}\text { Eight one primary } \\
\text { school }\end{array}$} & count & 20 & 38 & 32 & 12 \\
\hline & & $\begin{array}{c}\% \text { in } \\
\text { school }\end{array}$ & $52.6 \%$ & $100.0 \%$ & $84.2 \%$ & $31.6 \%$ \\
\hline & \multirow{2}{*}{$\begin{array}{l}\text { Lu Hongzha } \\
\text { primary school }\end{array}$} & count & 12 & 28 & 22 & 4 \\
\hline & & $\begin{array}{c}\% \text { in } \\
\text { school }\end{array}$ & $40.0 \%$ & $93.3 \%$ & $73.3 \%$ & $13.3 \%$ \\
\hline & \multirow{2}{*}{$\begin{array}{c}\text { Development Zone } \\
\text { Experimental } \\
\text { Primary School }\end{array}$} & count & 46 & 70 & 58 & 16 \\
\hline & & $\begin{array}{c}\% \text { in } \\
\text { school }\end{array}$ & $62.2 \%$ & $94.6 \%$ & $78.4 \%$ & $21.6 \%$ \\
\hline \multirow{2}{*}{\multicolumn{2}{|c|}{ total }} & count & 78 & 136 & 112 & 32 \\
\hline & & $\%$ of total & $54.9 \%$ & $95.8 \%$ & $78.9 \%$ & $22.5 \%$ \\
\hline
\end{tabular}

Table2-8. Chi-Square Tests

\begin{tabular}{|c|c|c|c|c|c|c|c|c|c|}
\hline & \multirow[t]{3}{*}{ Value } & \multirow[t]{3}{*}{ df } & \multirow{3}{*}{$\begin{array}{l}\text { Asymp. } \\
\text { Sig. (2- } \\
\text { sided) }\end{array}$} & \multicolumn{3}{|c|}{ Monte Carlo Sig. (2-sided) } & \multicolumn{3}{|c|}{ Monte Carlo Sig. (1-sided) } \\
\hline & & & & \multirow[t]{2}{*}{ Sig. } & \multicolumn{2}{|c|}{$95 \%$ Confidence Interval } & \multirow[t]{2}{*}{ Sig. } & \multicolumn{2}{|c|}{$95 \%$ Confidence Interva } \\
\hline & & & & & $\begin{array}{l}\text { Lower } \\
\text { Bound }\end{array}$ & $\begin{array}{l}\text { Upper } \\
\text { Bound }\end{array}$ & & $\begin{array}{l}\text { Lower } \\
\text { Bound }\end{array}$ & $\begin{array}{l}\text { Upper } \\
\text { Bound }\end{array}$ \\
\hline $\begin{array}{l}\text { Pearson Chi- } \\
\text { Square }\end{array}$ & $3.254^{\mathrm{a}}$ & 6 & .776 & $.785^{\mathrm{b}}$ & .777 & .793 & & & \\
\hline Likelihood Ratio & 3.251 & 6 & .777 & $.788^{\mathrm{b}}$ & .780 & .796 & & & \\
\hline $\begin{array}{c}\text { Fisher's Exact } \\
\text { Test }\end{array}$ & 3.104 & & & $.805^{\mathrm{b}}$ & .797 & .812 & & & \\
\hline $\begin{array}{c}\text { Linear-by-Linear } \\
\text { Association }\end{array}$ & $1.174^{\mathrm{c}}$ & 1 & .279 & $.281^{\mathrm{b}}$ & .272 & .290 & $.147^{\mathrm{b}}$ & .140 & .154 \\
\hline $\mathrm{N}$ of Valid Cases & 358 & & & & & & & & \\
\hline
\end{tabular}

As shown in table 2-7, a total of 142 people, per teacher can choose three options. The total number of selections is less than or equal to 426 ( $3 \times 142$ ); As shown in table 2-8, the number of valid cases is 358. Therefore the statistic is valid. According to the table 2-8, the variable of school has no significant result on teachers' awareness of the aspects of self evaluation (with a probability of more than 0.05).

Teachers do not want to only use the teaching results to measure themselves, evaluate themselves, but prefer to the virtue, ability, enthusiasm for teaching, students' care, education ideals and beliefs as the basis for self evaluation.

\subsection{Teachers' Evaluation of Students}

\subsubsection{The Influence of Teachers' Self Evaluation on Students' Development}

As shown in Table 2-9, a total of 142 people, per teacher can choose two options. The total number of selections is less than or equal to 284 ( $2 \times 142)$; As shown in table 2-10, the number of valid cases is 242.Thereforethe statistic is valid. According to the table 2-10, the variable of school has no significant result on the impact of teacher's self evaluation on student development (with a probability of more than 0.05).

It can be seen that the majority of teachers can discover the problems which are existing in students' development through their own feelings. Based on this, teacher can further solve the problems existing in the development of students. Finally achieve the goal-- promoting the development of students. More than half of the teachers think that teachers' self evaluation has a close contact with students' self evaluation, so that both teachers and students can realize that collaborative development, 


\section{Zhiquan Zhang et al.}

mutual benefit and win-win. Of course, there are very few teachers' sensitivity is not strong, they think self-assessment cannot influence students development. Or even individual teachers' consciousness is weak. They have never been so concerned about this problem.

Table2-9. The influence of teachers' self evaluation on students' development

\begin{tabular}{|c|c|c|c|c|c|c|}
\hline & \multicolumn{4}{|c|}{$\begin{array}{l}\text { What is the impact of teacher's self evaluation on student } \\
\text { development? }\end{array}$} \\
\hline & & & $\begin{array}{l}\text { Teachers' self } \\
\text { evaluation will } \\
\text { affect students' } \\
\text { self evaluation }\end{array}$ & $\begin{array}{l}\text { Teachers find the } \\
\text { problems in the } \\
\text { development of } \\
\text { students by feeling } \\
\text { their own changes. }\end{array}$ & $\begin{array}{c}\text { Have little } \\
\text { influence on } \\
\text { the } \\
\text { development } \\
\text { of students }\end{array}$ & $\begin{array}{c}\text { Never paid } \\
\text { attention to } \\
\text { this } \\
\text { problem }\end{array}$ \\
\hline \multirow[t]{6}{*}{ school } & \multirow{2}{*}{$\begin{array}{l}\text { Eight one primary } \\
\text { school }\end{array}$} & count & 30 & 36 & 4 & 0 \\
\hline & & $\%$ in school & $78.9 \%$ & $94.7 \%$ & $10.5 \%$ & $0.0 \%$ \\
\hline & \multirow{2}{*}{$\begin{array}{l}\text { Lu Hongzha } \\
\text { primary school }\end{array}$} & count & 20 & 28 & 0 & 0 \\
\hline & & $\%$ in school & $66.7 \%$ & $93.3 \%$ & $0.0 \%$ & $0.0 \%$ \\
\hline & \multirow{2}{*}{$\begin{array}{l}\text { Development Zone } \\
\text { Experimental } \\
\text { Primary School }\end{array}$} & count & 54 & 64 & 4 & 2 \\
\hline & & $\%$ in school & $73.0 \%$ & $86.5 \%$ & $5.4 \%$ & $2.7 \%$ \\
\hline \multirow{2}{*}{\multicolumn{2}{|c|}{ total }} & count & 104 & 128 & 8 & 2 \\
\hline & & $\%$ of total & $73.2 \%$ & $90.1 \%$ & $5.6 \%$ & $1.4 \%$ \\
\hline
\end{tabular}

Table2-10. Chi-Square Tests

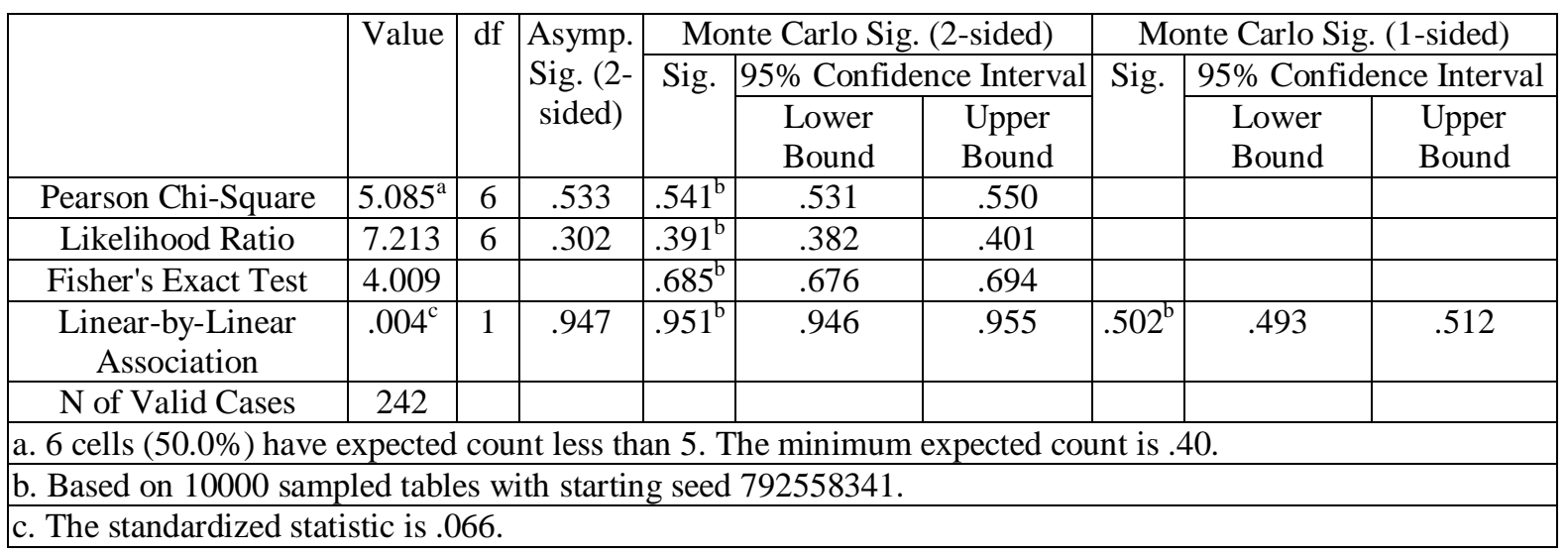

\subsubsection{Teachers' Attitude toward the Evaluation of Students in Teachers' Evaluation}

Table 2-11. Teachers' attitude toward the evaluation of students in Teachers' evaluation

\begin{tabular}{|c|c|c|c|c|c|c|}
\hline & \multicolumn{4}{|c|}{$\begin{array}{l}\text { Do you think students should be an important part } \\
\text { of the evaluation of teachers as a teacher? }\end{array}$} \\
\hline & & & very agree & agree & indifferent & disagree \\
\hline \multirow[t]{6}{*}{ school } & \multirow[t]{2}{*}{ Eight one primary school } & count & 4 & 28 & 6 & 0 \\
\hline & & $\%$ in school & $10.5 \%$ & $73.7 \%$ & $15.8 \%$ & $0.0 \%$ \\
\hline & \multirow{2}{*}{$\begin{array}{l}\text { Lu Hongzha primary } \\
\text { school }\end{array}$} & count & 4 & 26 & 0 & 0 \\
\hline & & $\%$ in school & $13.3 \%$ & $86.7 \%$ & $0.0 \%$ & $0.0 \%$ \\
\hline & \multirow{2}{*}{$\begin{array}{c}\text { Development Zone } \\
\text { Experimental Primary } \\
\text { School }\end{array}$} & count & 18 & 36 & 6 & 14 \\
\hline & & $\%$ in school & $24.3 \%$ & $48.6 \%$ & $8.1 \%$ & $18.9 \%$ \\
\hline \multirow{2}{*}{\multicolumn{2}{|c|}{ total }} & count & 26 & 90 & 12 & 14 \\
\hline & & $\%$ of total & $18.3 \%$ & $63.4 \%$ & $8.5 \%$ & $9.9 \%$ \\
\hline
\end{tabular}

Table2-12. Chi-Square Tests

\begin{tabular}{|c|c|c|c|c|c|c|c|c|c|}
\hline & \multirow[t]{3}{*}{ Value } & \multirow[t]{3}{*}{$\mathrm{df}$} & \multirow{3}{*}{$\begin{array}{c}\text { Asymp. } \\
\text { Sig. } \\
\text { (2- } \\
\text { sided) }\end{array}$} & \multicolumn{3}{|c|}{ Monte Carlo Sig. (2-sided) } & \multicolumn{3}{|c|}{ Monte Carlo Sig. (1-sided) } \\
\hline & & & & \multirow[t]{2}{*}{ Sig. } & \multicolumn{2}{|c|}{$95 \%$ Confidence Interval } & \multirow[t]{2}{*}{ Sig. } & \multicolumn{2}{|c|}{$95 \%$ Confidence Interval } \\
\hline & & & & & $\begin{array}{l}\text { Lower } \\
\text { Bound }\end{array}$ & $\begin{array}{l}\text { Upper } \\
\text { Bound }\end{array}$ & & $\begin{array}{l}\text { Lower } \\
\text { Bound }\end{array}$ & $\begin{array}{l}\text { Upper } \\
\text { Bound }\end{array}$ \\
\hline Pearson Chi-Square & $26.694^{\mathrm{a}}$ & 6 & .000 & $.000^{\mathrm{b}}$ & .000 & .000 & & & \\
\hline Likelihood Ratio & 34.174 & 6 & .000 & $.000^{b}$ & .000 & .000 & & & \\
\hline Fisher's Exact Test & 26.305 & & & $.000^{b}$ & .000 & .000 & & & \\
\hline Linear-by-Linear & $1.616^{\mathrm{c}}$ & 1 & 204 & $.223^{\mathrm{b}}$ & .215 & .231 & $.107^{\mathrm{b}}$ & .101 & .113 \\
\hline
\end{tabular}


The Current Situation of Primary School Teacher's Evaluation in China-Take the Several Schools in Nantong City as Example

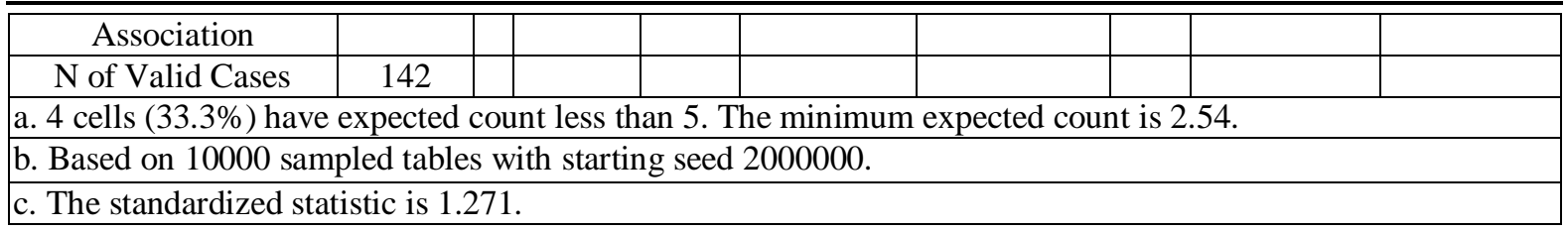

According to the table 2-12, the variable of school has very significant result on teachers' attitude toward the evaluation of students in Teachers' evaluation(with a probability of less than 0.005 ).

More than $80 \%$ of the teachers are in favor of the student evaluation as an important part in teacher' evaluation. It indicates that the teachers are still very concerned about the students' opinions. Of course, there are the remaining less than $20 \%$ of the teachers hold negative attitude to this problem.

\subsection{Students' Evaluation to Teachers}

2.4.1. The type of teachers' teaching which students like

Table2-13. The type of teachers' teaching which students like $(N=373)$

\begin{tabular}{|c|c|c|c|c|c|c|}
\hline & \multicolumn{4}{|c|}{ If let you choose, which kind of teaching do you like? } \\
\hline & & & $\begin{array}{c}\text { Only the } \\
\text { teacher speak } \\
\text { in class }\end{array}$ & $\begin{array}{c}\text { Teachers and } \\
\text { students together } \\
\text { to discuss }\end{array}$ & $\begin{array}{l}\text { Group learning in } \\
\text { cooperation with } \\
\text { several students }\end{array}$ & $\begin{array}{l}\text { Outdoor } \\
\text { learning }\end{array}$ \\
\hline \multirow[t]{6}{*}{ school } & \multirow{2}{*}{$\begin{array}{c}\text { Eight one primary } \\
\text { school }\end{array}$} & count & 16 & 95 & 67 & 54 \\
\hline & & $\%$ in school & $6.9 \%$ & $40.9 \%$ & $28.9 \%$ & $23.3 \%$ \\
\hline & \multirow{2}{*}{$\begin{array}{l}\text { Lu Hongzha } \\
\text { primary school }\end{array}$} & count & 17 & 98 & 74 & 82 \\
\hline & & $\%$ in school & $6.3 \%$ & $36.2 \%$ & $27.3 \%$ & $30.3 \%$ \\
\hline & \multirow{2}{*}{$\begin{array}{l}\text { Development Zone } \\
\text { Experimental } \\
\text { Primary School }\end{array}$} & count & 10 & 65 & 39 & 20 \\
\hline & & $\%$ in school & $7.5 \%$ & $48.5 \%$ & $29.1 \%$ & $14.9 \%$ \\
\hline \multirow{2}{*}{\multicolumn{2}{|c|}{ total }} & count & 43 & 258 & 180 & 156 \\
\hline & & $\%$ of total & $6.8 \%$ & $40.5 \%$ & $28.3 \%$ & $24.5 \%$ \\
\hline
\end{tabular}

Table2-14. Chi-Square Tests

\begin{tabular}{|c|c|c|c|c|c|c|c|c|c|}
\hline & \multirow[t]{3}{*}{ Value } & \multirow[t]{3}{*}{ df } & \multirow{3}{*}{$\begin{array}{c}\text { Asymp. } \\
\text { Sig. (2- } \\
\text { sided) }\end{array}$} & \multicolumn{3}{|c|}{ Monte Carlo Sig. (2-sided) } & \multicolumn{3}{|c|}{ Monte Carlo Sig. (1-sided) } \\
\hline & & & & \multirow[t]{2}{*}{ Sig. } & \multicolumn{2}{|c|}{$95 \%$ Confidence Interval } & \multirow[t]{2}{*}{ Sig. } & \multicolumn{2}{|c|}{$95 \%$ Confidence Interval } \\
\hline & & & & & $\begin{array}{l}\text { Lower } \\
\text { Bound }\end{array}$ & $\begin{array}{l}\text { Upper } \\
\text { Bound }\end{array}$ & & $\begin{array}{l}\text { Lower } \\
\text { Bound }\end{array}$ & $\begin{array}{l}\text { Upper } \\
\text { Bound }\end{array}$ \\
\hline Pearson Chi-Square & $12.571^{\mathrm{a}}$ & 6 & .050 & $.052^{\mathrm{b}}$ & .047 & .056 & & & \\
\hline Likelihood Ratio & 13.053 & 6 & .042 & $.045^{\mathrm{b}}$ & .041 & .049 & & & \\
\hline Fisher's Exact Test & 12.919 & & & $.043^{b}$ & .039 & .047 & & & \\
\hline $\begin{array}{c}\text { Linear-by-Linear } \\
\text { Association }\end{array}$ & $1.496^{\mathrm{c}}$ & 1 & .221 & $.233^{\mathrm{b}}$ & .225 & .241 & $.121^{\mathrm{b}}$ & .115 & .127 \\
\hline $\mathrm{N}$ of Valid Cases & 637 & & & & & & & & \\
\hline \multicolumn{10}{|c|}{ a. 0 cells $(0.0 \%)$ have expected count less than 5 . The minimum expected count is 9.05 . } \\
\hline \multicolumn{10}{|c|}{ b. Based on 10000 sampled tables with starting seed 1634676757.} \\
\hline \multicolumn{10}{|c|}{ c. The standardized statistic is -1.223 . } \\
\hline
\end{tabular}

As shown in Table 2-13, a total of 373 people, per student can choose two options. The total number of selections is less than or equal to 746 ( $2 \times 373)$; As shown in table 2-14, the number of valid cases is 637.Therefore the statistic is valid. According to the table 2-14, the variable of school has faint significant result on the type of teachers' teaching which students like (with a probability of equal to $0.05)$.

Other investigation shows that students dislike the teachers who play a serious and eccentric role. They dislike the following behaviors of teachers, which are assigning too much homework and striking students' confidence. The standards which used to evaluate teachers by students is often based on the teacher's behaviors that they don't like.

\section{DisCuSSION AND ANALYSIS}

3.1. School is an important executive power to promote the evaluation of teachers. The quality of teacher evaluation is closely related to the strength and way of school teacher evaluation. The theory and policy concern about teachers' evaluation is weak and lack, and the low efficiency of the organization of teachers' evaluation will directly affect the work of teacher evaluation, and 


\section{Zhiquan Zhang et al.}

further affect the quality of school education and national education quality. Therefore, the school level should do a good job in the study and promotion of teacher evaluation policy and theory, follow the paces of the Teacher evaluation policy and theory, developing teacher evaluation in an orderly manner according to the realistic situation.

3.2. Teachers' educational practice should be the practice of virtue, that is, the practice of moral practice. ${ }^{[1]}$ In the evaluation of teachers concerned about the teacher's virtue is also student, teacher and education' s hope. Teachers pay more attention to the evaluation of teachers' morality, which helps to guide teachers to pay attention to their own moral cultivation, and further become a favorite teacher, set a good example for the students.

3.3. Teacher evaluation needs to learn and introduce a variety of teacher evaluation methods, such as teachers' ability testing, rating scale, classroom observation, clinical evaluation, student evaluation of teaching, clinical guidance, peer evaluation, student test scores, the career ladder and teacher portfolio. ${ }^{[2]}$ In order to replace the single evaluation method. Through a wide range of methods we carry out a reasonable and scientific evaluation of teachers.

3.4. For the understanding of the connotation of teacher evaluation, there are differences and common understanding between teachers and students in school. Therefore, it is necessary to give full play to the positive role of inter subjectivity to promote mutual understanding. Inter subjectivity is a kind of negotiation and dialogue activity, which is taken as the main body in the thought and behavior. ${ }^{[3]}$ Since then, school understands the teachers' understanding of evaluation, students understand the teachers' understanding of evaluation, teachers understand students' expectations for excellent teachers, teachers understand the expectations of the school for excellent teachers. Schools, teachers and students are consistent with the vision of excellent teachers. Therefore, teachers should pay more attention to the requirements of students for teachers and listen to the voice of the students; Schools need to know more about teachers and pay more attention to the teacher's self evaluation.

\section{REFERENCES}

[1] Li Fangan. Research on teacher self development [J]. Education, 2015, 04:94-99.

[2] T. Husen, T. n. Bosiersi waite editor, Zhang Lili proofreader. Education encyclopedia, education evaluation [M]. Chongqing: Southwest China Normal University Press, 2011.132-133.

[3] Zhang Zhiquan, Cai Chenyun. Research on the interaction of educational theory and practice in the perspective of inter subjectivity [J]. Contemporary educational science, 2014, 22:7-10.

AUTHORS' BIOGRAPHY

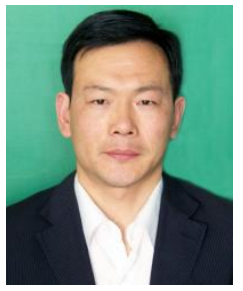

Zhi-quan Zhang (1972-), male, born in YanZhou county ShanDong province, vice professor of Nantong university, doctor, research on educational principle theory.TL:13814717635

Jie yin (1993-), male, born in Nan Tong city, postgraduate, studying educational principle theory in educational faculty in Nantong university.

Chenyun CAI (1992-) female, born in YiXing county, postgraduate, studying educational principle theory in educational faculty in Nantong university.

This article is the achievement of Colleges and Universities Philosophy and Social Sciences project of Jiangsu province: Research on the dynamic evaluation of teachers' professional development,

Approve No: 2014SJB623. 